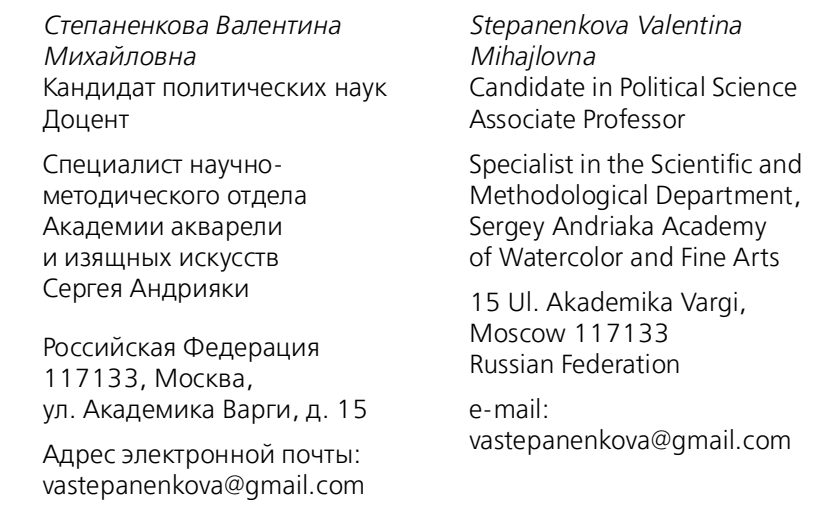

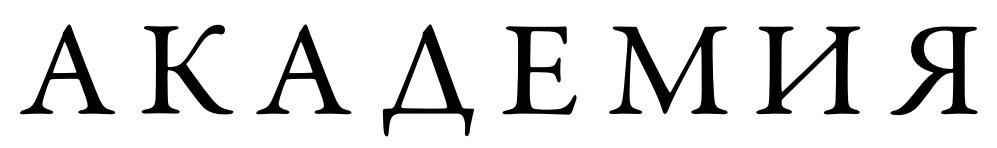

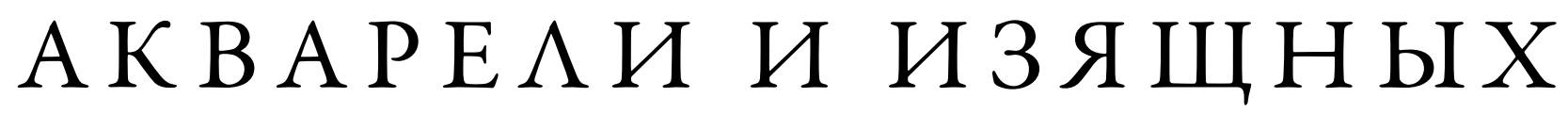
$\AA$ И СК У С С В

\section{СЕРГЕЯ АНАРИЯКИ}

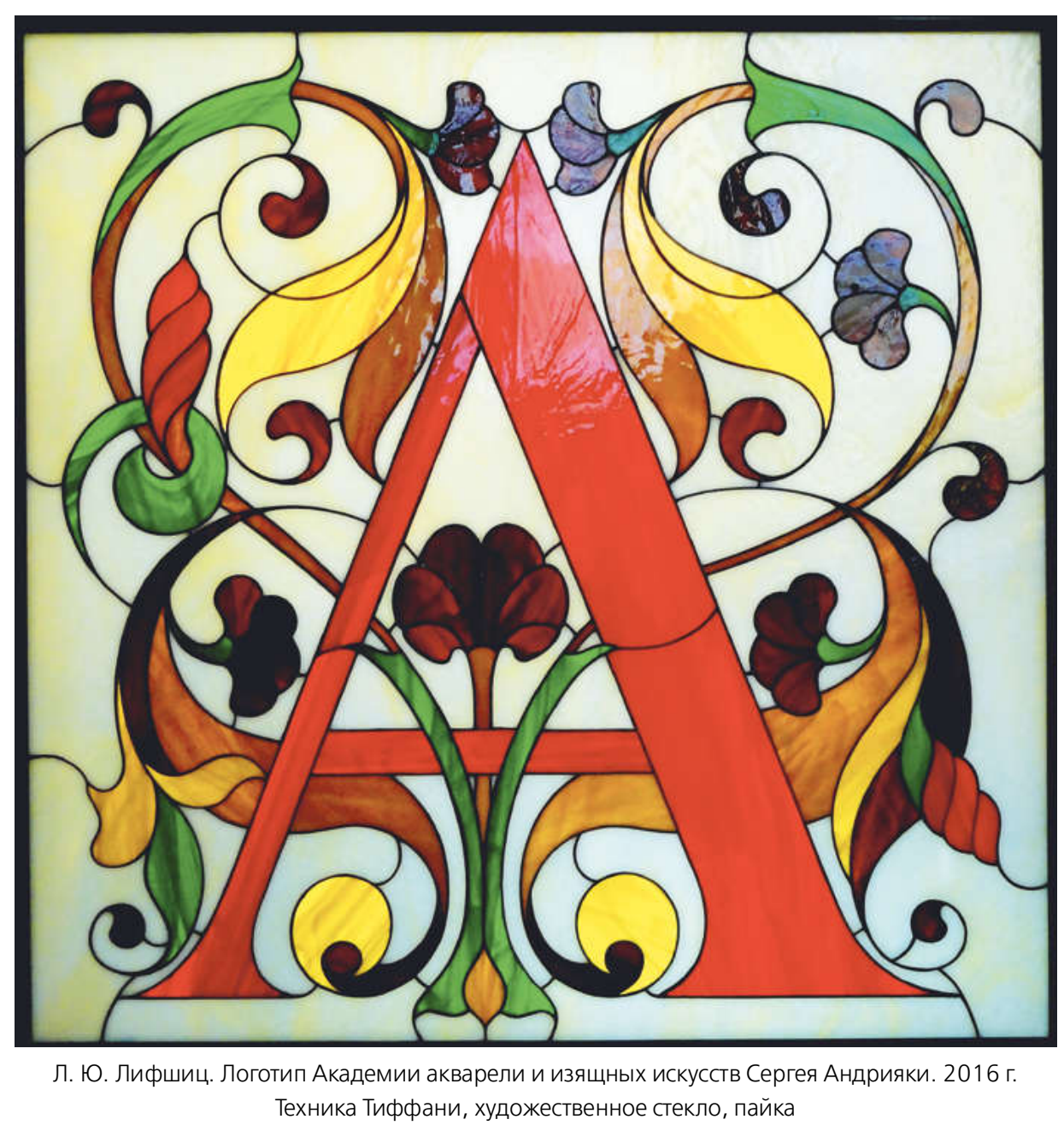

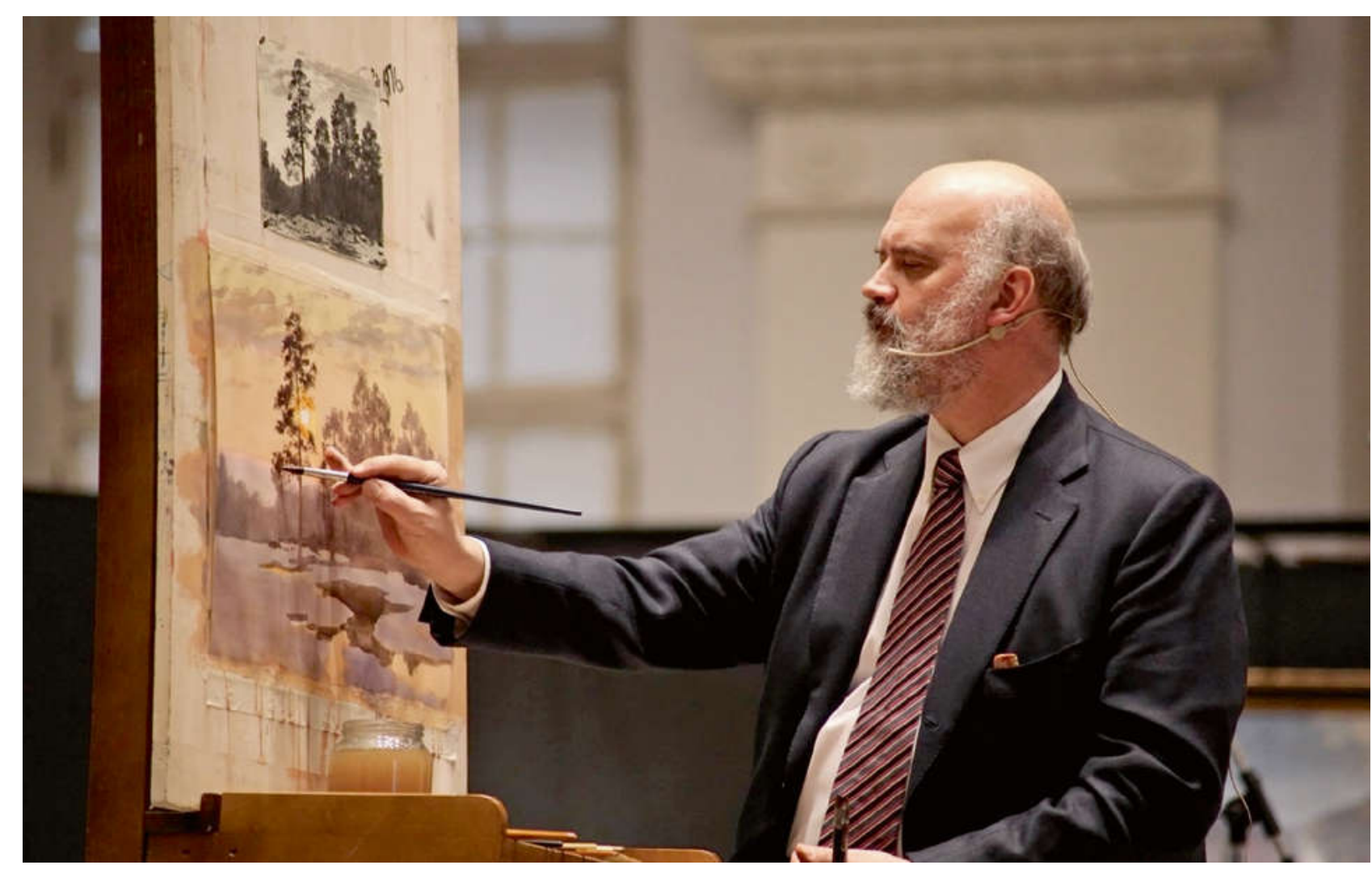

Академия акварели и изящных искусств Сергея Андрияки - уникальное учебное заведени, Предавание в котором построено теля. Пе дагогическая система С. Н. Андрияки базируется на высокоэффективном методе Бо наглядного обучения, при котором худож- Бу ник-педагог выполняет все задания учебной программы параллельно со студентами, демонстрируя им алгоритм работы, помогая преодолевать трудности и решать сложные творческие задачи. - Академия акварели воспинывае ваивет наибиверсала: каждый студент осизобразительолее востребованные техники мический рисунок, акварельную, масляну живопись, пастель, иконопись или светскую темперную живопись, скульптуру, настенную роспись, римскую и флорентийскую мозаику, витражное искусство, основы книжной график, офорл, роспись по керамике и фарфодела, основы дизай на, рестаррацио маслитй, темперной живописи и графики. Овладение практическими навыками в области монументального и декоративно-прикладного искусства происходит путем колмективного исполнения государственного, корпоративного или частного заказа. Сре проектов, участие в которых приняли студенты Академии, - исследовательская и творческая работа по воссозданию исторического облика Московского Кремля, выполненная для Управления делами Президента России, создание витражных арочных сводов храма Воскресения Христова - главного храма

\section{неж». Москва, 2017 г.}

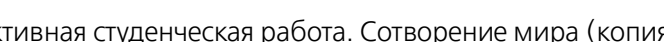

$\rightarrow$

иков, П. Е. Рябинский. Кремлевский звон. Вид на кии монастыри от Красной площади.
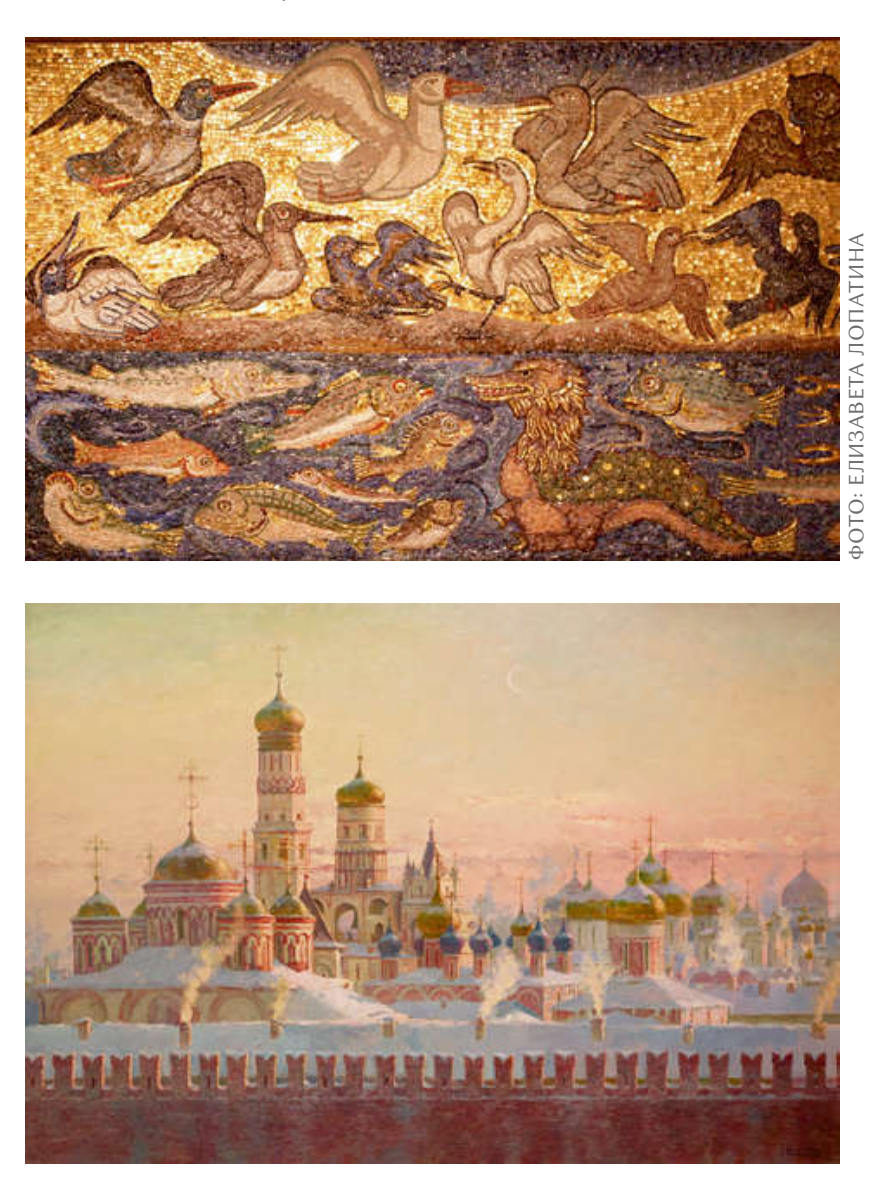


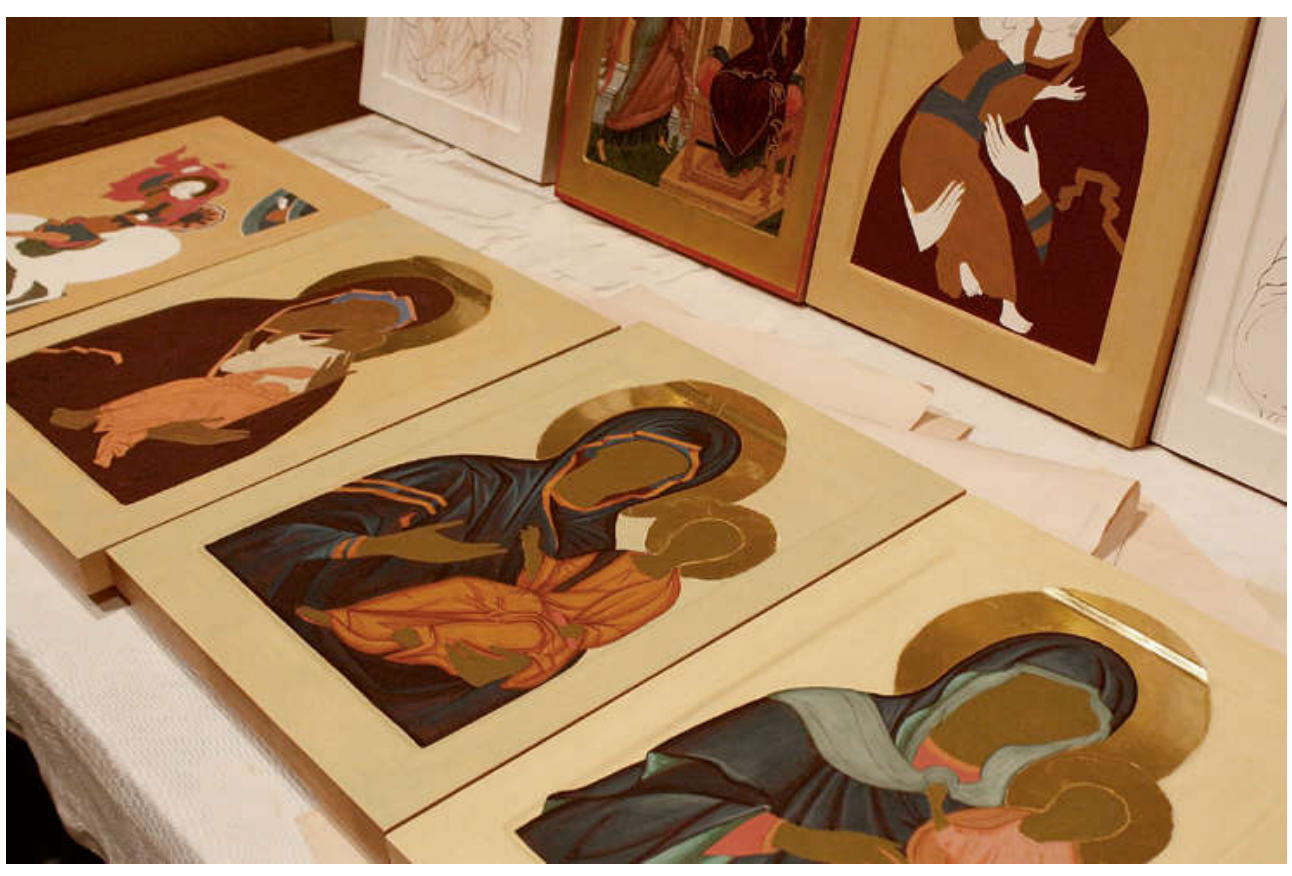

Мастерская
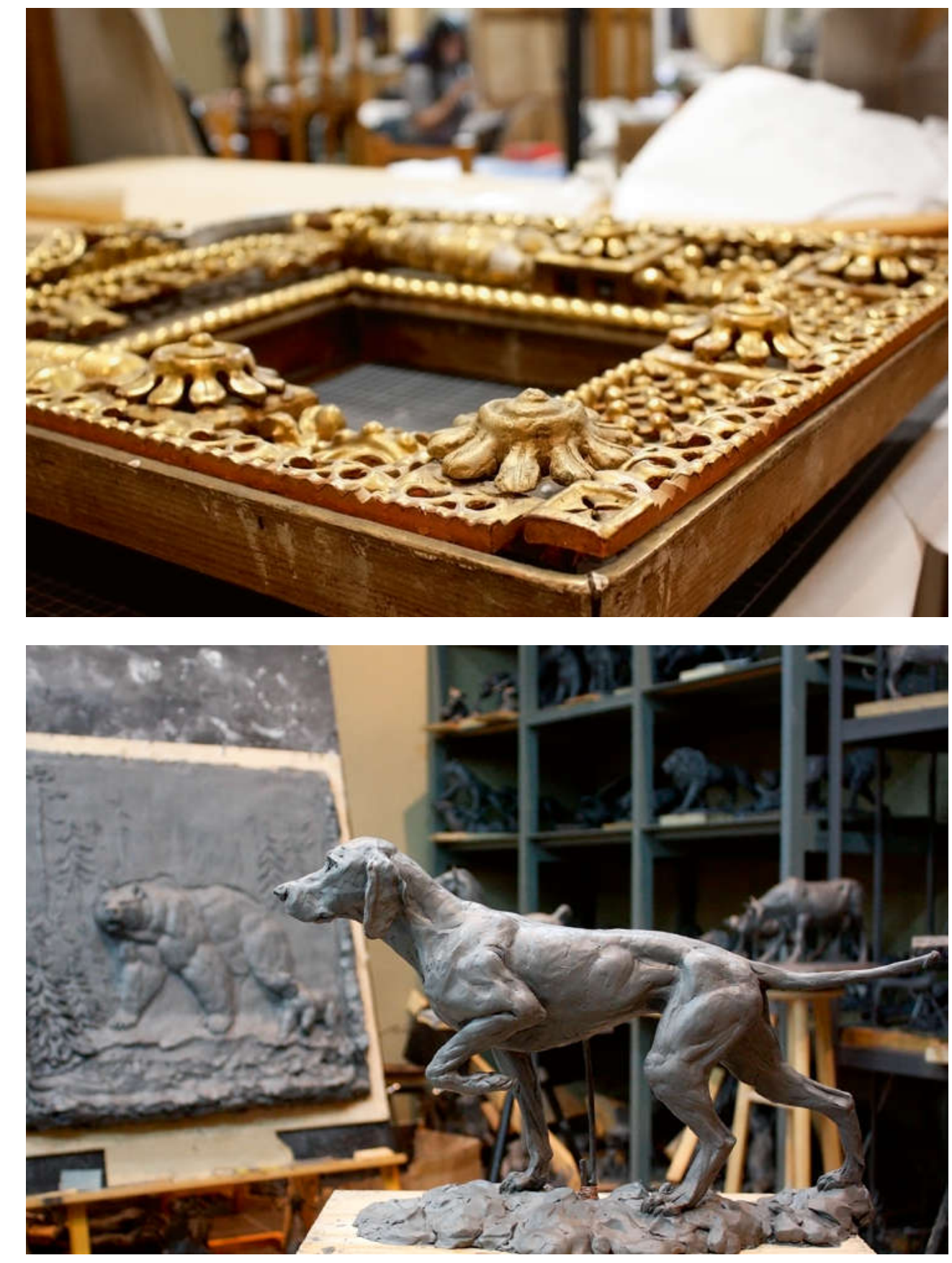

Мастерская реставрации

темперной

живописи
Вооруженных Сил России, работа над керамическими панно по заказу префектуры Центрального административного округа Москвы. студентам Вуз безвозмездно предоставляет сля выпомнения зананий по учебним про-

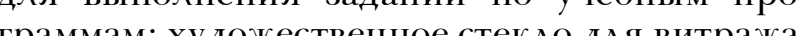
смальту и природный камень дая мозаики; пергамент дал миниатюр; эмали дия росписи фарфора, керамини и стекса; золото дия иконописи и т. д.

В здании Академии оборудованы профильные учебные мастерские, оснащенные станками лазерной и гидроабразивной резки камня, фьюзинговыми, муфельными печами и др. Будущие мастера имеют уникальную возможность работать на современном оборудовании с использованием материалов лучших зарубежных производителей.

Выставочная деятельность - неотьемлемая часть учебного процесса. В Музейно-выставочном комплексе (МВК) Академии, площадь которого составляет около трех тысяч квадрапных метров, экспонируются педевры живописи, графики и декоративно-прикладного искусства из фондов федеральных,
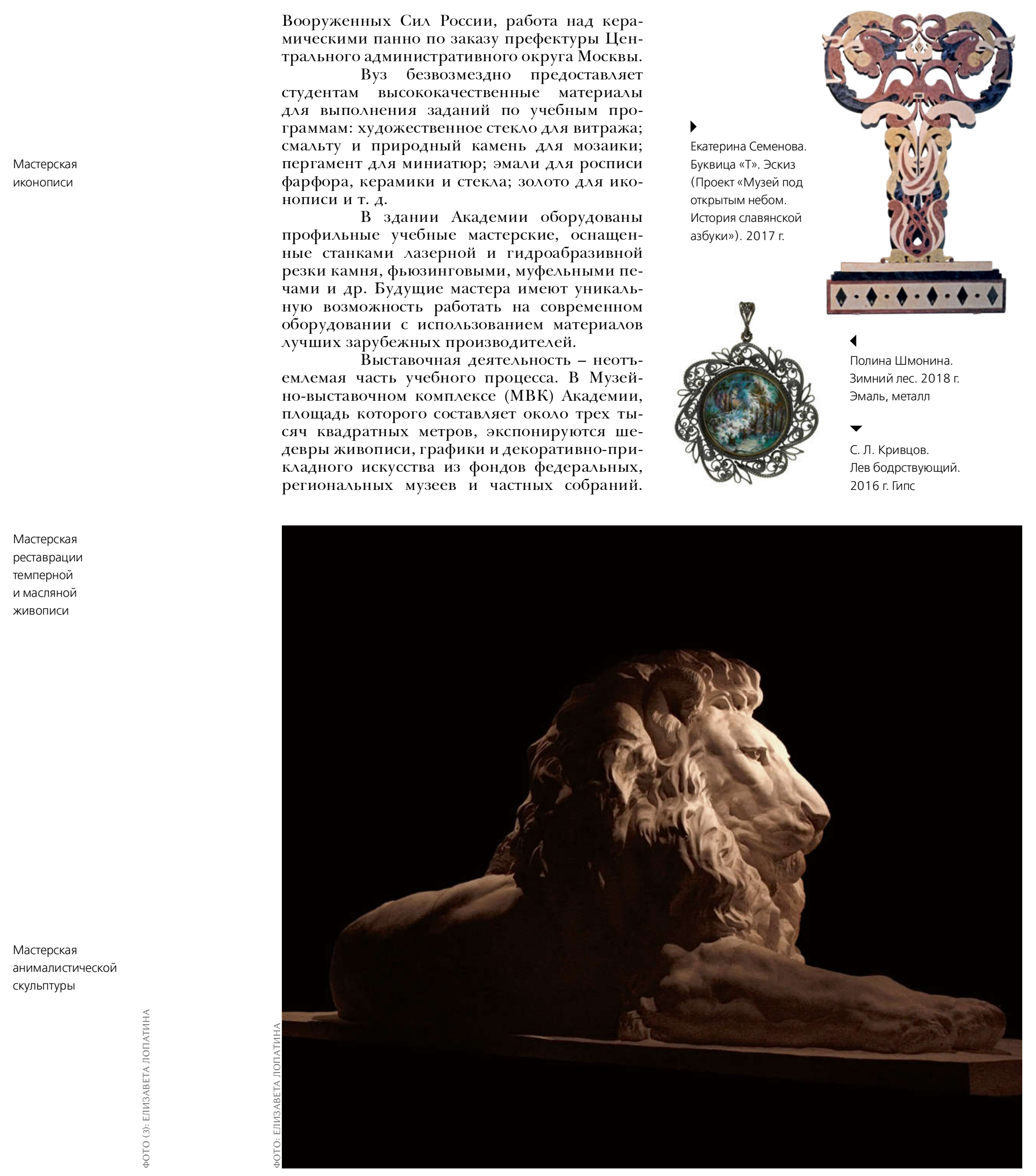

Мастерская скульптуры 


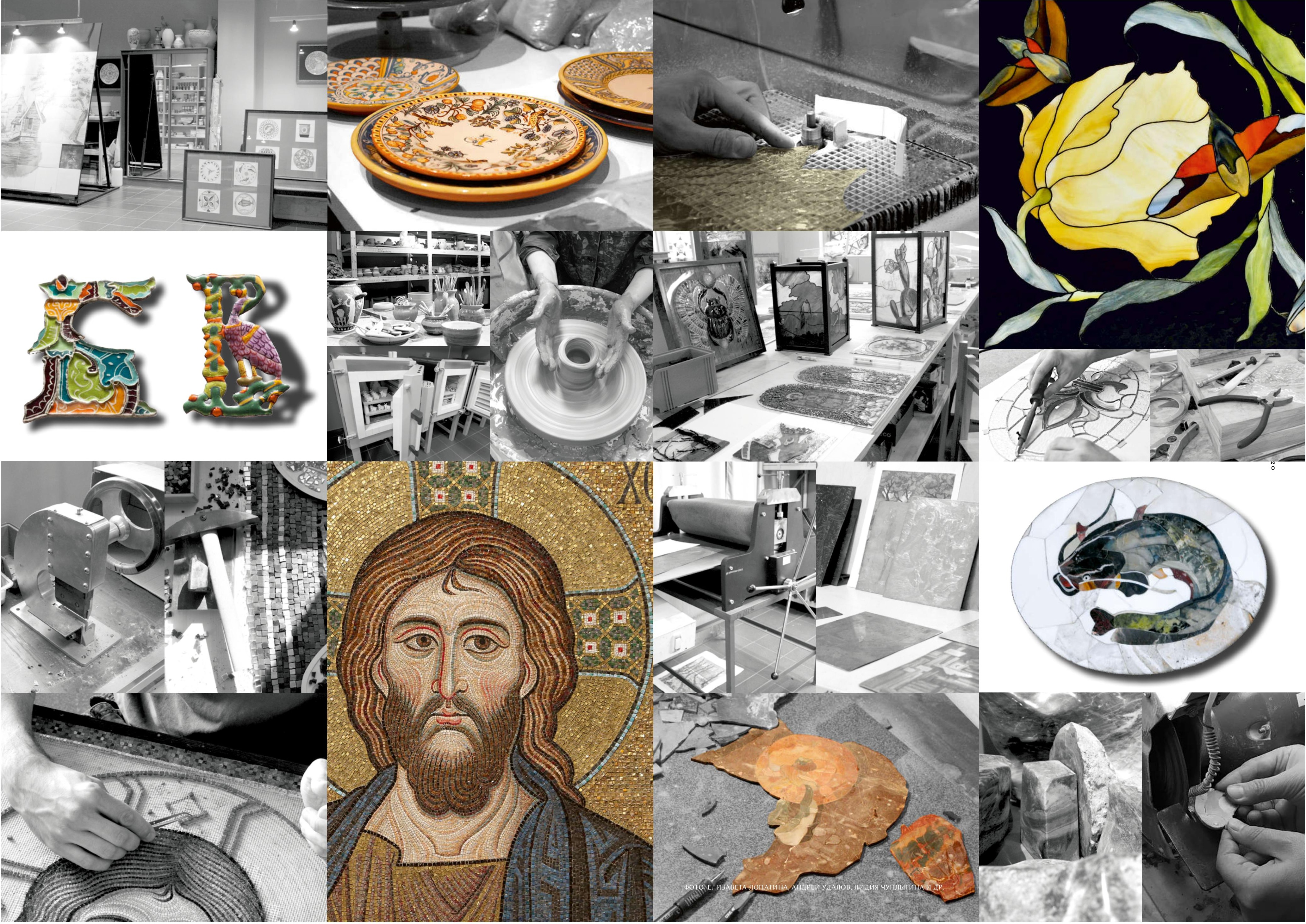




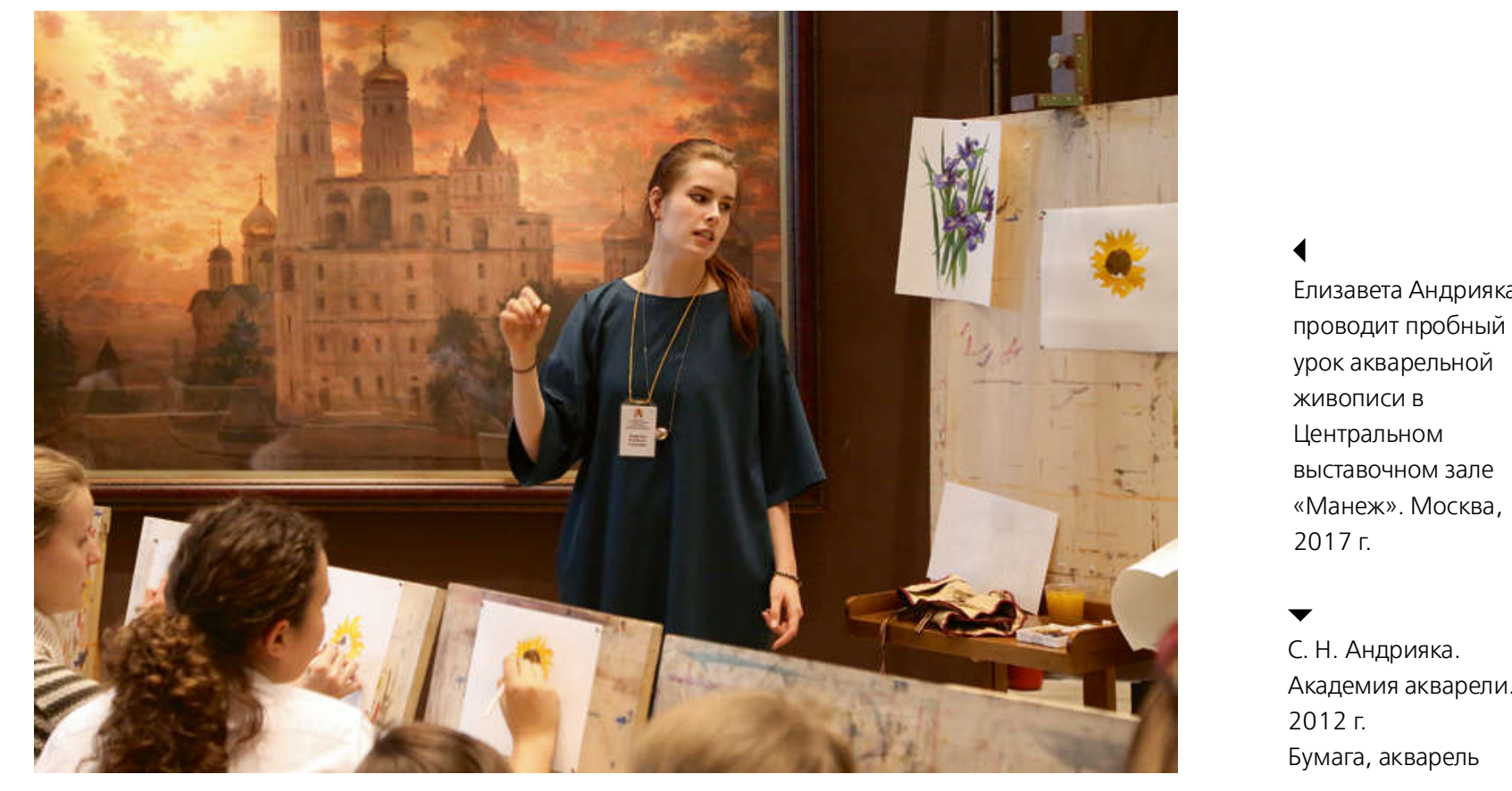

МВК ежегодно организует около 60 вы-

Непосредственно в здании вуза тов за рубежом, а тақже в отечественных 36 тысяч квадратных метров, имеются коммузеях, галереях и культурных центрах. фортабельное общежитие, киноконцертны

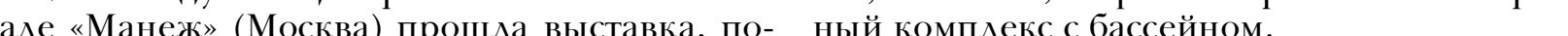
рой били представлены более 4000 проторой бий художников-педагогов и студентов.

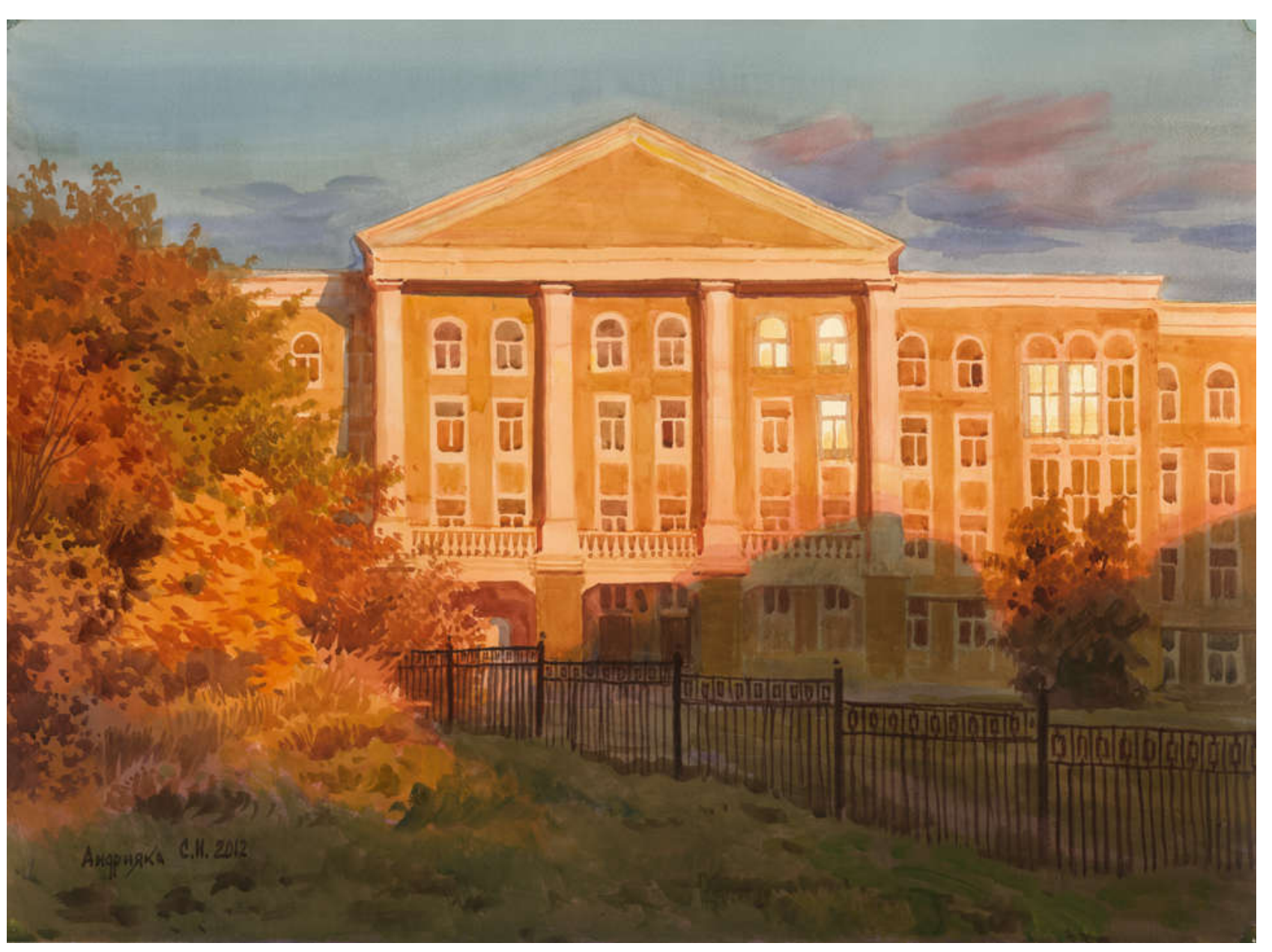

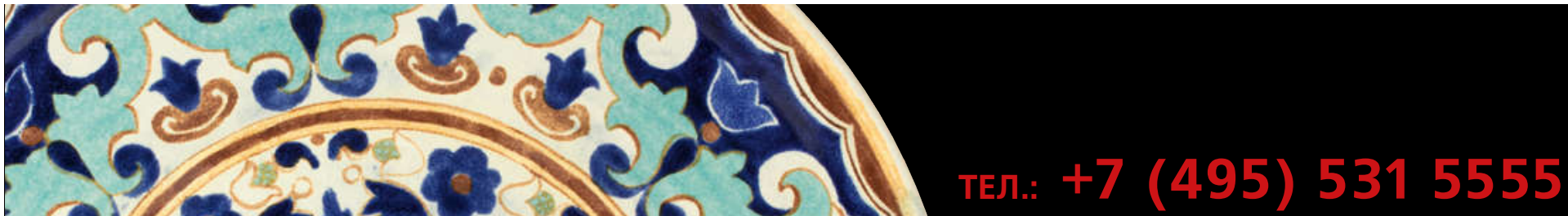

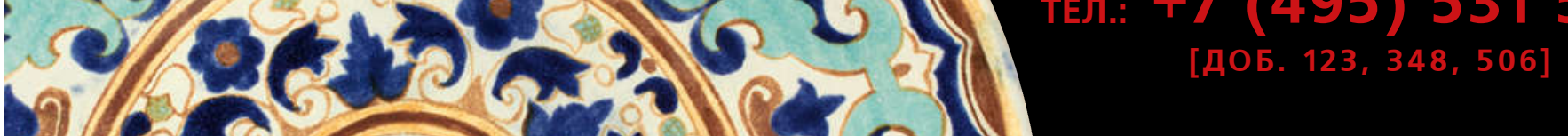
- 25

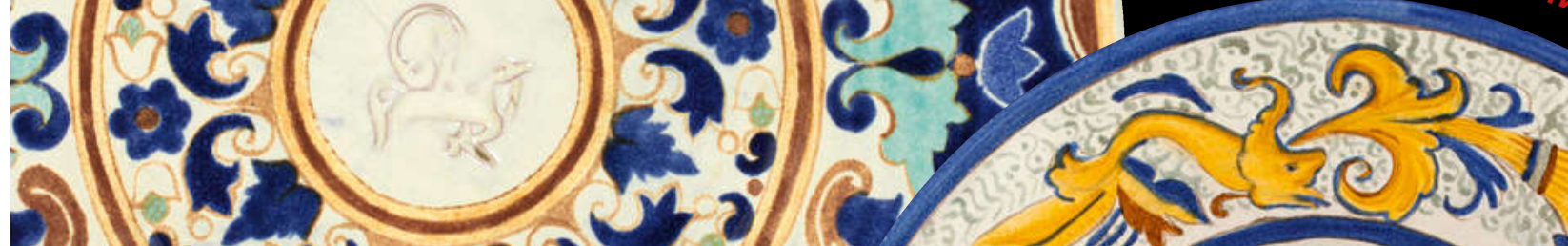

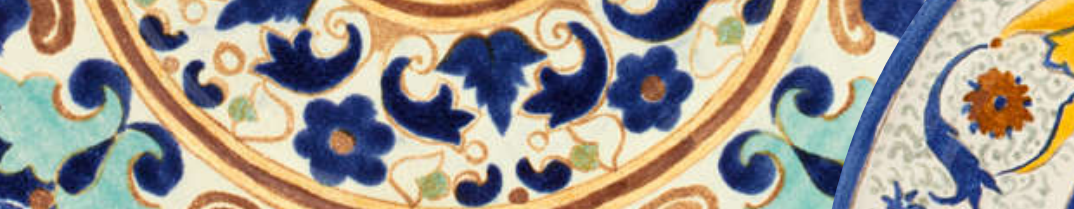
L OCHOBDl

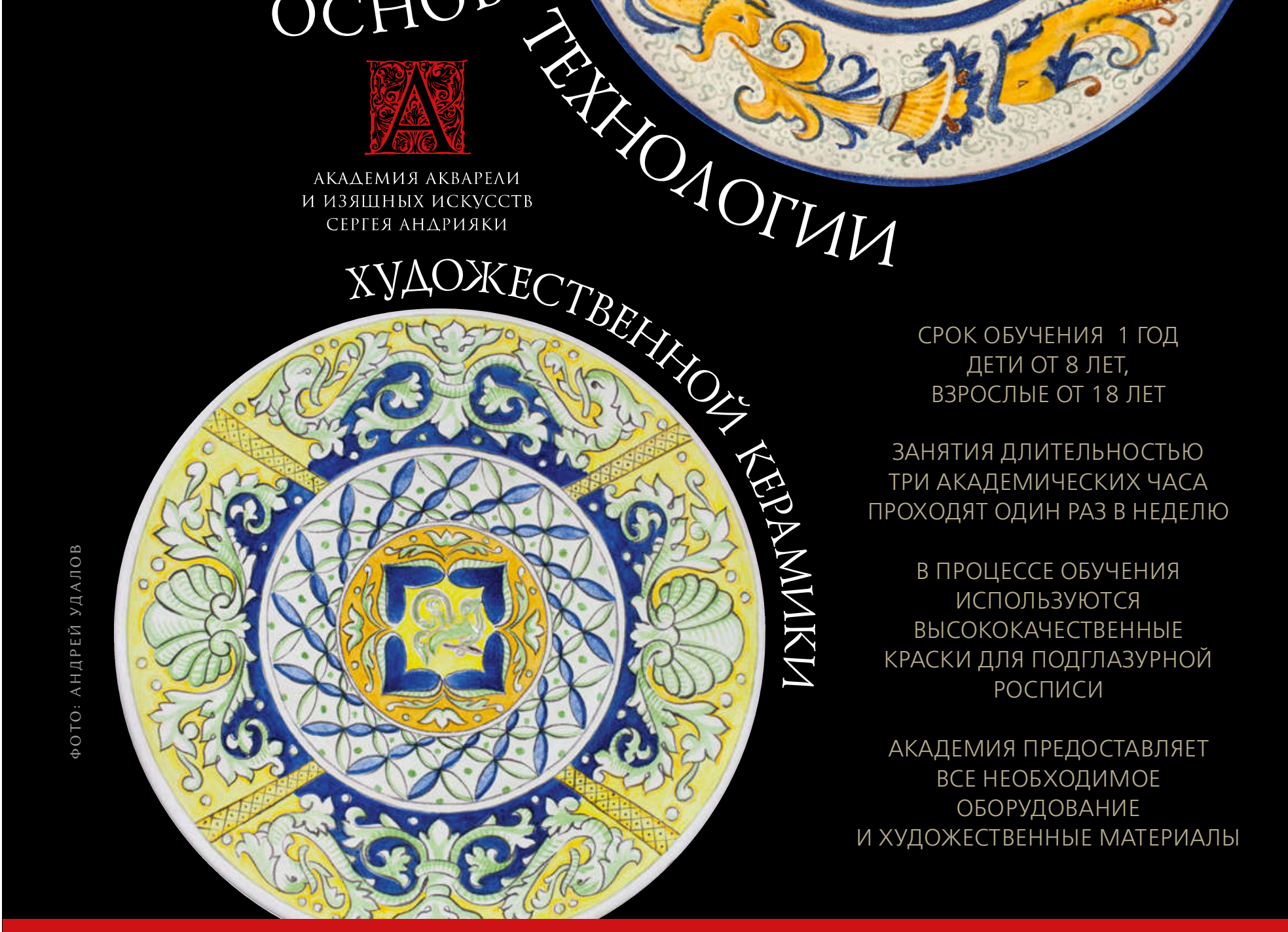

ЗАКАЗ КЕРАМИКИ И ФАРФОРА: +7 (495) 5315555 MASTERSKIE@ACADEMY-ANDRIAKA.RU АВТОРСКИЕ РАБОТЫ, КОПИИ, МОНУМЕНТАЛЬНЫЕ ПРОЕКТЫ, ЭЛЕМЕНТЫ ДЕКОРА ИНТЕРЬЕРА 